\title{
Ureter metastatic castration-resistant prostate cancer: a case report
}

\author{
Sohgo Tsutsumi ${ }^{1}$, Takashi Kawahara ${ }^{* *}$ (D), Yusuke Hattori ${ }^{1}$, Taku Mochizuki ${ }^{1}$, Jun-ichi Teranishi ${ }^{1}, Y^{2}$ asuhide Miyoshi ${ }^{1}$, \\ Sawako Chiba ${ }^{2}$ and Hiroji Uemura ${ }^{1}$
}

\begin{abstract}
Background: In most cases, prostate cancer metastasizes to the lymph nodes, bone, and liver. In very rare cases, it metastasizes to the ureter. Due to the difficulty in making a preoperative diagnosis, ureteral metastasis from prostate cancer is typically diagnosed after nephroureterectomy.

Case presentation: A 77-year-old Asian Japanese man with right hydronephrosis and hydroureter was referred to our hospital to undergo further examination due to the suspicion of ureteral cancer. He had been diagnosed 2 years previously with prostate cancer with a Gleason score of $4+5=9$. He received radiotherapy and androgen deprivation therapy. A nephroureterectomy was performed for suspected right ureteral cancer. On the basis of a histopathological examination, poorly differentiated adenocarcinoma was suspected, and the tumor cells were positive for prostatespecific antigen immunohistochemically.
\end{abstract}

Conclusions: We herein report a rare case of ureteral metastasis in castration resistant prostate cancer.

Keywords: Skene's gland adenocarcinoma, Skene's gland cancer, Female PSA

\section{Background}

In most cases, prostate cancer metastasizes to the lymph nodes, bone, and liver. In very rare cases, it metastasizes to the ureter [1]. Due to the difficulty in obtaining a preoperative diagnosis, ureteral metastasis from prostate cancer is typically diagnosed on the basis of examination of nephron specimens obtained at ureterectomy. We report an extremely rare case involving a patient with ureteral metastasis from prostate cancer.

\section{Case presentation}

A 77-year-old Asian Japanese man with suspected ureteral cancer was referred to our hospital to undergo further examination for right hydronephrosis and hydroureter in September 2016. He had undergone resection for cecal cancer and had been diagnosed with prostate cancer 2 years previously with a Gleason score of $4+5=9$. He received radiotherapy with androgen deprivation therapy (ADT) for

\footnotetext{
*Correspondence: takashi_tk2001@yahoo.co.jp

${ }^{1}$ Departments of Urology and Renal Transplantation, Yokohama City

University Medical Center, Yokohama, Japan

Full list of author information is available at the end of the article
}

cT2N0M0 prostate cancer. The patient's initial prostate-specific antigen (PSA) level was $14.66 \mathrm{ng} / \mathrm{ml}$ in 2014. Although the initial response was good, his PSA level increased to $0.417 \mathrm{ng} / \mathrm{ml}$ with continuous ADT (testosterone $0.30 \mathrm{ng} / \mathrm{ml}$ ) from a nadir of 0.006 $\mathrm{ng} / \mathrm{ml}$ in 2016. The results of a laboratory analysis were almost within normal limits, with the exception of a slightly elevated creatinine level $(1.31 \mathrm{mg} / \mathrm{dl})$ and a slightly decreased hemoglobin level $(12.6 \mathrm{ng} / \mathrm{dl})$. Urinalysis revealed no abnormalities, and urine cytology showed no atypical cells. Enhanced computed tomography showed right hydronephrosis and hydroureter from a lower ureteral mass with enhancement (Fig. 1). Retrograde pyelography showed complete obstruction of the right ureter (Fig. 2). Although the patient had castration-resistant prostate cancer (CRPC), the median overall survival was around 3 years at our institute, and the patient requested to undergo curative surgery for his ureteral tumor.

On the basis of these findings, we suspected right ureteral cancer and performed a nephroureterectomy in December 2016. The ureter showed strong adhesion to the peritoneum and was partially removed with the peritoneum. The resected specimen measured $16 \mathrm{~cm} \times 2 \mathrm{~cm}$ 


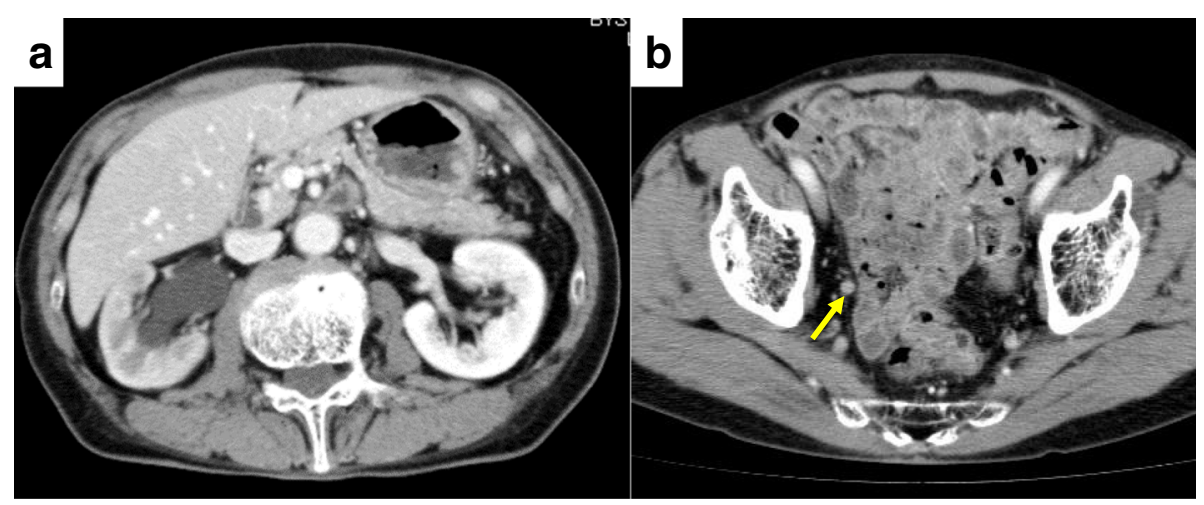

Fig. 1 Computed tomographic findings of (a) hydronephrosis and (b) the patient's tumor (arrow)

in size, and the tumor was observed to have extended to the surface of the resected tissue.

Histologically, the ureteral epithelium was normal. In the intra- and extraureteral tissue, tumor cells that had enlarged round nuclei with visible nucleoli were proliferated with a solid pattern. The tumor showed a little glandular differentiation. Poorly differentiated adenocarcinoma was suspected. The result of immunochemical staining for PSA was positive (Fig. 3). On the basis of these findings, the patient was diagnosed with ureteral metastasis from prostate cancer. The patient continues to receive therapy for CRPC.

\section{Discussion}

Disibio et al. noted that prostate cancer was likely to metastasize to the lymph nodes (26.2\%), bone (19.7\%), lung (12.8\%), and liver (7.8\%) [1]. Ureteral metastasis from prostate cancer is a very rare disease, with only 44 reported cases [2]. It is hypothesized that ureteral metastasis is rare in patients with prostate cancer because the lymph stream is not connected around the

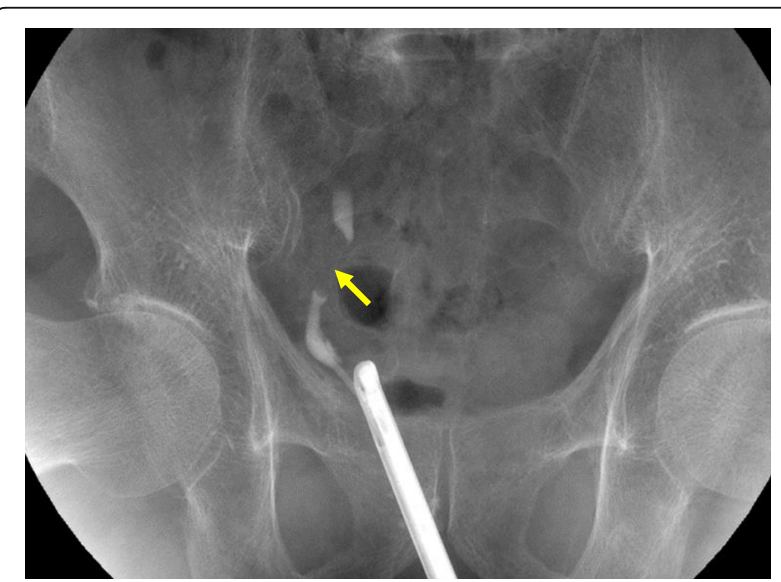

Fig. 2 Retrograde pyelonephrography. Stenosis was observed in the lower ureter (arrow) ureter [3]. Most patients with ureteral metastasis have primary breast or gastric cancer, whereas some have colon or cervical cancer $[4,5]$.

Metastatic ureteral tumors are difficult to differentiate from ureteral urothelial carcinoma. Presman et al. reported that metastatic ureteral tumors were diagnosed because (1) tumor cells were confirmed in the lymph nodes and vessels around the ureter, or (2) the same cancer cells as the original cancer tissue were detected in the ureteral wall without direct invasion [6]. Metastatic ureteral tumors tend not to adhere to the mucosa, owing to a poor lymphoid and visceral network [6]. For these reasons, pain due to ureteral obstruction is the chief complaint of patients with this type of tumor. In most cases, the tumor is found in the submucosa, and urine cytology is not useful in making the diagnosis. Given recent developments with ureteroscopy, a ureteroscopic biopsy might be useful. However, because of the small sample size, the pathological diagnosis is sometimes difficult.

On one hand, it is hypothesized that the identification of ureteral obstruction and hydronephrosis may be used to make an early diagnosis. On the other hand, patients with benign prostatic hyperplasia and ureteral stones may also show these symptoms. In patients with prostate cancer, ureteral obstruction usually originates from direct invasion from an enlarged tumor around the ureterovesicular junction [7]. In most cases, direct invasion is observed in the bilateral ureterovesicular junction. In our patient, the ureteral obstruction was unilateral and was outside the ureterovesicular junction. In such cases, a ureteroscopic biopsy might be used to make a preoperative diagnosis. However, this strategy is not superior to retrograde pyelography. Fortunately, CRPC treatment does not require favorable renal function, even when cytotoxic treatments are used, including docetaxel and cabazitaxel, so radical nephroureterectomy is sometimes performed. 


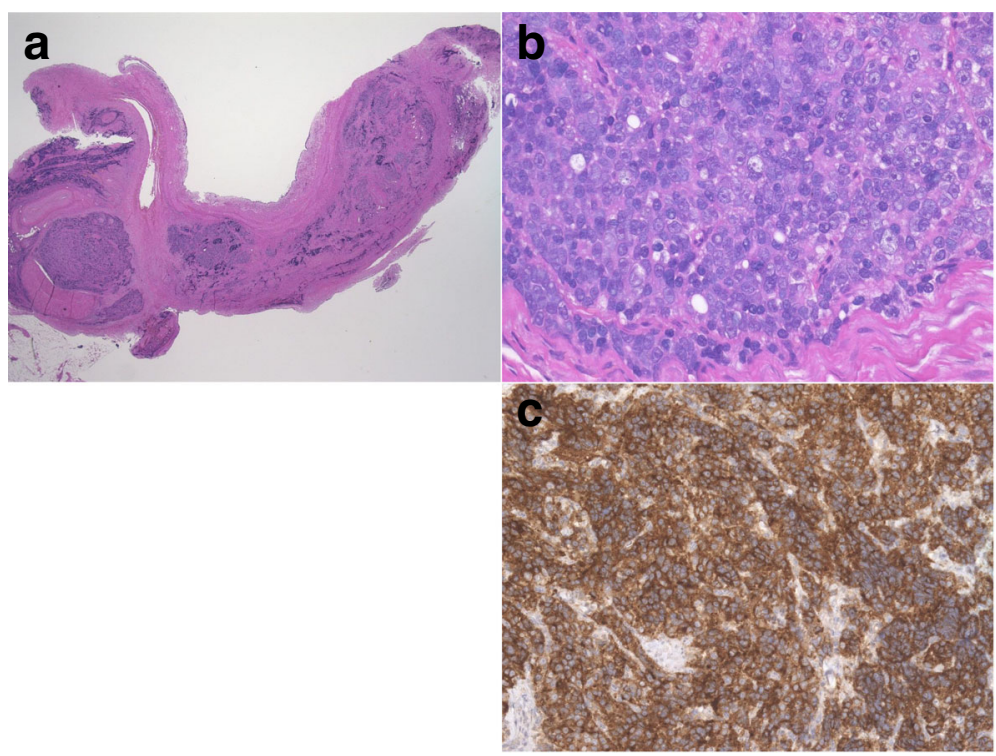

Fig. 3 Pathological images. a Ureteral epithelium was intact. Solid metastatic nest in intra- and extraureteral wall (hematoxylin and eosin stain, original magnification $\times 12.5$ ). $\mathbf{b}$ Tumor showed a little glandular differentiation (hematoxylin and eosin stain, original magnification $\times 400$ ). c Tumor cells stained positive for prostate-specific antigen (original magnification $\times 200$ )

\section{Conclusions}

We herein report a rare case of ureteral metastasis in castration resistant prostate cancer.

\section{Acknowledgements}

Not applicable.

\section{Funding}

This work was supported by a Grant-in-Aid for Scientific Research (KAKENHI) (16K20152) from the Ministry of Education, Culture, Sports, Science and Technology of Japan and a grant from the 2016-2017 Research Development Fund (WJ2810) of Yokohama City University,

\section{Availability of data and materials}

Due to ethical restrictions, the raw data underlying this paper are available only upon request submitted to the corresponding author.

\section{Authors' contributions}

ST, JT, and SC conceived of and designed the experiments. ST, TK, and SC analyzed data. ST, TK, YH, TM, JT, YM, HU performed the experiments. ST, TK, and SC wrote the paper. All authors read and approved the final manuscript.

\section{Ethics approval and consent to participate}

The present study was approved by the institutional review board of Yokohama City University Medical Center.

\section{Consent for publication}

Written informed consent was obtained from the patient for publication of this case report and any accompanying images. A copy of the written consent is available for review by the Editor-in-Chief of this journal.

\section{Competing interests}

The authors declare that they have no competing interests.

\section{Publisher's Note}

Springer Nature remains neutral with regard to jurisdictional claims in published maps and institutional affiliations.

\section{Author details}

${ }^{1}$ Departments of Urology and Renal Transplantation, Yokohama City University Medical Center, Yokohama, Japan. ${ }^{2}$ Department of Diagnostic Pathology, Yokohama City University Medical Center, Yokohama, Japan.

Received: 11 April 2017 Accepted: 27 May 2017

Published online: 06 September 2017

\section{References}

1. Disibio G, French SW. Metastatic patterns of cancers: results from a large autopsy study. Arch Pathol Lab Med. 2008;132(6):931-9.

2. Otta RJ, Gordillo C, Fernández I. Ureteral metastasis of a prostatic adenocarcinoma. Can Urol Assoc J. 2015;9(3-4):E153-5.

3. Carson WJ. Metastatic carcinoma in the ureter: report of additional cases. Ann Surg. 1927:86(4):549-55.

4. Fitch WP, Robinson JR, Radwin HW. Metastatic carcinoma of the ureter. Arch Surg. 1976;111(8):874-6.

5. Zhang D, Li H, Gan W. Hydronephrosis associated with ureteral metastasis of prostate cancer: a rare case report. Mol Clin Oncol. 2016;4(4):597-8.

6. Presman D, Ehrlich L. Metastatic tumors of the ureter. J Urol. 1948;59(3):312-25.

7. Zollinger 2nd RW, Wise 2nd HA, Clausen KP. An unusual presentation of intrinsic ureteral obstruction secondary to carcinoma of the prostate: a case report. J Urol. 1981;125(1):132-3.

Submit your next manuscript to BioMed Central and we will help you at every step:

- We accept pre-submission inquiries

- Our selector tool helps you to find the most relevant journal

- We provide round the clock customer support

- Convenient online submission

- Thorough peer review

- Inclusion in PubMed and all major indexing services

- Maximum visibility for your research

Submit your manuscript at www.biomedcentral.com/submit
C Biomed Central 